http://dx.doi.org/10.15762/ZH.2017.24

WOJCIECH POLAK

(Nicolaus Copernicus University in Toruń)

SYLWIA GALIJ-SKARBIŃSKA

(Nicolaus Copernicus University in Toruń)

\title{
A Polish Model of the Intelligence Service Reform in 1990
}

Key words: the Security Service, the Office of State Protection, verification, the Ministry of Internal Affair

Krzysztof Kozłowski - the first head of the intelligence service newly established in 1990 - in an interview discussing the first months of the activities of the Office of State Protection [Urząd Ochrony Państwa - UOP], admitted: "[...] We observed significant changes in regards to the embassy of the USSR, which employed 450 people. In the past, in Poland, operational officers who were fed up of working in the West, exhausted, and were thought to deserve some rest before retirement were employed. A nice city, good salary, access to Pewex, ${ }^{1}$ easy work and everything was good. It was enough to pick up a receiver and make a phone call. There was big intelligence potential in Poland, but why use it when everything was handed to them on a plate?. When decisions were made to replace, the embassy personnel with a network of young operational officers based on patterns existing in the West. So, at a time when the Americans and the Germans were observing us with a certain degree of reservation, disbelief and distrust, the Soviets, above everybody, classified our country as a western one. It is known that the USSR was first in all areas and this was no exception". ${ }^{2}$

${ }^{1}$ The Internal Export Company "Pewex" - a state company with its headquarters in Warsaw, running a network of shops and exchange offices in the Polish People's Republic [Polska Rzeczpospolita Ludowa - further cit. PRL], where one could buy (using other currencies) Polish and imported goods unavailable or hard to get in other shops.

${ }^{2}$ Historia $z$ Konsekwencjami. Rozmawiają Krzysztof Kozłowski i Michał Komar, Warszawa 2009, p. 261. 
It has to be admitted that the changes taking place in the Polish secret service caused some anxiety not only in the USSR, but also in western countries. The changes started in the autumn of 1989 , relatively late in relation to other reforms resulting from the "Round Table" discussions. ${ }^{3}$

\section{THE PROBLEM OF REFORM \\ IN POST-COMMUNIST COUNTRIES}

Generally speaking, in all authoritarian systems (including the previous Soviet Bloc), the secret service was a key tool in maintaining and keeping power. According to Michael Warner, the atmosphere of a country can be presented as consisting of competing social classes and religions, which "swarm with damage-doers, saboteurs and kulaks." In such a case, a security service apparatus is established in order to control, threaten, manipulate and repress real or imaginary enemies of "the only right ideology" both in the country and abroad and is no respecter of human rights and freedoms but concerns itself with the interests, not of the country and its citizens, but of its political leaders. ${ }^{4}$

In countries with military regimes, the security service is supervised directly by the army. In communist systems, intelligence and counterintelligence were under a mixture of military and intelligence service control. In both cases, however, problems associated with their reforms were similar. ${ }^{5}$

For countries starting the democratization process, in addition to the political, social and economic changes taking place, an important issue was reform of the secret service, which meant moving away from a repressive and unaccountable system of state security towards the creation of one supervised by civil authorities.

When discussing secret service reform in post-communist countries, it should be noted that there were two types of solutions of varying gradualist forms.

The first extreme referred to the so called "zero option," which called for the reassembling of the secret service from scratch. According to Larry Watts,

${ }^{3}$ The first basic reforms were implemented in November 1989, when two coercive institutions of the PRL were liquidated: The Voluntary Reserve of Civic Militia and the Religion Office. Then work started on legislative projects such as the prevention of security and public order. Only in February did legislative projects regarding the reforms of, among others, the Ministry of Internal Affairs and the Security Service go to Parliament.

${ }^{4}$ See: Michael Warner, Building a Theory of Intelligence Systems. In Mapping the State of Research on Intelligence, New York 2009.

${ }^{5}$ Thomas C. Bruneau, Kenneth R. Dombroski, Reforming Intelligence: The Challenge of Control in New Democracies, [in:] Who Guards the Guardians and How. Democratic Civil-Military Relations, ed. Thomas C. Bruneau, Scott D. Tollefso, Austin 2006, pp. 151-152. 
whose statement is based on research concerning Eastern European regimes: in some countries there was a tendency to liquidate the previously existing secret service, rather than rebuild it. It was a natural process resulting from a desire to destroy a symbol of oppression and terror. ${ }^{6}$ This process took place in countries which wished to totally dissociate themselves from communist regimes. One of such country was Czechoslovakia, which was the first to take radical actions in creating a de-communization act, and was indeed the first country to pass such a law. This so called "zero option" model assumed:

- the liquidation of the old disgraced structures of the previous regime,

- the impossibility for previous officials to work in newly created structures and any other state institutions,

- the holding of former secret service officials to account even if the actions they were responsible for, were not considered illegal in accordance with previous laws.

On the other side of this continuum, there was a model, which assumed the continuing existence of the communist secret service without any changes concerning its shape and personnel (only the names were changed). However, it was to be focused on the fulfilling the needs of the new governing authorities. A characteristic feature of this was that even a cursory vetting process was not envisaged. Adopting such a measure was characteristic of countries where the downfall of communism was perceived to be the result of a political system transformation, and a result of decisions jointly taken by the opposition and communist party reformers. Therefore, in the beginning, there was not an unequivocal break with the previous system of governance, and a gradual reconstruction path was adopted ${ }^{7}$ instead.

In these countries numerous gradualist forms of secret service reform were applied characterized by adopting different solutions for such issues as: organizational structure, position in the structure of state authorities, working methods and personnel replacement (including management).

The important factors, which influenced the direction of changes in the secret service were:

- the level of keeping the same personnel, buildings and other assets of nondemocratic institutions,

- a lack of any verified working norms and standards,

${ }^{6}$ Larry WatTs, Intelligence Reform in Europe's Emerging Democracies, Studies in Intelligence, Vol. 48: 2004, No. 1.

${ }^{7}$ For more information concerning transformations in the countries of Central and Eastern Europe see: Kieran Williams, Dennis Deletant, Security Intelligence Services in New Democracies The Czech Republic, Slovakia and Romania, London 2001. 
- a lack of experience and knowledge of those in charge concerning the security service,

- a lack of real involvement by the government, which was much more concentrated on economic and political reforms, resulting in superficial initiatives in regard to secret service reforms (miserly allocated goods and poor management). ${ }^{8}$

Kieran Williams provides three variables, which influenced the way the reforms were implemented:

- how much of the communist system was preserved at the time of the changes in 1989,

- the communists' attitude towards the negotiations (whether they were willing to take part in negotiations or were resistant to change),

- the result of the first election after 1989. ${ }^{9}$

Undoubtedly, all these factors were important for post-communist countries in choosing their path to a new secret service.

\section{BETWEEN LIQUIDATION AND CONTINUATION - THE POLISH EXAMPLE}

Poland was among a number of countries, which emerged from the crisis of a liquidated Security Service [Służba Bezpieczeństwa - SB] to build a monolithic intelligence service, concentrated on one institution - the Office of State Protection. The Office of State Protection was established on April 6 ${ }^{\text {th }}, 1990$ and from then on was expected to perform intelligence and counterintelligence activities. This was a bone of contention during the parliamentary debates as this idea was adopted from the previous regime. As such, it raised fears that the newly created Office of State Protection would continue the previous regime's action strategy. These fears, represented mainly by right wing politicians, were stoked by making the Office of State Protection report directly to the Ministry of Internal Affairs [Ministerstwo Spraw Wewnętrznych - MSW] leaving open to question a lack of effective control and supervision of the newly formed secret service. Therefore, what was required was to liquidate the intelligence service, and to establish a military secret service, or to separate intelligence from the Office of State Protection, or to make the Office of State Protection report to the government.

However, the main problem concerned the personnel of the newly erected structure. During discussions on parliamentary projects on February $9^{\text {th }}$,

${ }^{8}$ Thomas C. Bruneau, Florina C. Matei, Intelligence in the Developing Democracies: The Quest for Transparency And Effectiveness, http://www.resdal.org/producciones-miembros/artbruneau-other-mar10.pdf [access: 22 XI 2015].

${ }^{9}$ Kieran Williams, Introduction, [in:] K. Williams, D. Deletant, op.cit., p. 19. 
1990, most politicians were of the opinion that the verification of previous Security Service officials was a natural way to establish personnel for the newly formed Office of State Protection. However, radical voices made themselves heard in a discussion predating the vote on enacting the act on the Office of State Protection on April $6^{\text {th }} 1990$, and during Senate deliberations concerning the acceptance of the act on April 26 $6^{\text {th }}$ 1990. It might be said that such a situation arose from changes, which took place in the Ministry of Internal Affairs, and from actions undertaken by Tadeusz Mazowiecki's government towards the department (appointing Krzysztof Kozłowski the Deputy Minister of Internal Affairs on March $6^{\text {th }}, 1990$ ). The more realistic dissolving of the department and rebuilding it from scratch was, the more politicians demanded the implementation of this so called "zero-option," which meant in practice the impossibility for any previous Security Service officials to find employment in the Office of State Protection. Amongst others, such an opinion was voiced by the politicians associated with the Parliamentary Civic Club [Obywatelski Klub Parlamentarny - OKP], the Polish Peasant Party [Polskie Stronnictwo Ludowe - PSL] "Odrodzenie," and the Democratic Party [Stronnictwo Demokratyczne - SD]. The idea of vetting was significantly supported by politicians congregated around the Parliamentary Club of the Democratic Left [Parlamentarny Klub Lewicy Demokratycznej], which originated from the Polish United Workers' Party [Polska Zjednoczona Partia Robotnicza - PZPR].

There were also ideas circulating calling for partial verification, which meant vetting intelligence officers, while rejecting other officials previously employed in other operational sectors. During Senate debates an idea was mooted encouraging short-term coexistence of the Security Service and the Office of State Protection. These two organizations would exist separately for a time in order to enable the Office of State Protection to take over previous activities of the Security Service. Implied in this proposal was that former Security Service officials were not allowed to be employed by the Office of State Protection. Another idea put forward referred to postponing the establishment of the Office of State Protection until a time when new personnel, capable of performing their activities, could be trained.

However, those in charge were against this aforementioned idea as they did not want to wait, claiming that the state could not be deprived of internal and external protection. Andrzej Milczanowski, first deputy and then head of the Office of State Protection, who was appointed on August $31^{\text {st }} 1990$, said after a few years that: "In rejecting the so called «zero option», together with Minister Kozłowski, we were of the opinion that in a situation of significant political system change, Poland had to have a fully operational ready secret service here and now. Open borders, denaturalization and the dysfunction which accompanied the process of creating free-market economy and others 
such as low levels of social discipline, the common drive to grow wealthy at any cost, changing alliances, more and more visible symptoms of a severe political and economic crisis in the USSR, and many other circumstances enforced the rejection of the "zero option»". 10

The Office of State Protection started to operate on May $10^{\text {th }} 1990$. Next day Krzysztof Kozłowski, the previous Deputy Minister of Internal Affairs, was appointed the head of the Office of State Protection by Tadeusz Mazowiecki. Pursuant to decree no. $043 / 90$ of May $10^{\text {th }}, 1990$, the Minister of Internal Affairs, General Czesław Kiszczak ordered the Security Service to cease activities. This decree did not apply to the intelligence and counterintelligence services as they "had significant importance for state protection, and for activities against people suspected of espionage or performing terrorist attacks". ${ }^{11}$ Similarly, the activities performed by the Cipher Bureau were to continue until the Office of State Protection was due to form on August $1^{\text {st }} 1990$.

At a local level, in Provincial Offices of Internal Affairs special boards were formed aimed at "supervising how well the implementation of the decree concerning liquidation of the Security Service" was being carried out. The boards made the heads of the departments make lists of useful and usable operational work tools and submit these in the form of documents to a committee' by June $6^{\text {th }} \cdot{ }^{12}$

A number of important issues are worthy of note at this juncture. At this time, from 1981, General Kiszczak was the Minister of Internal Affairs, and his deputies were the regime generals Henryk Dankowski and Zbigniew Pudysz. In addition, in the headquarters of the Ministry of Internal Affairs, in Rakowiecka Street, more than 7,000 people, including 30 generals were employed.

The act establishing the Office of State Protection, article no 132, put an onus on the Council of Ministers to specify, according to a decree, a procedure and conditions of acceptance into the Office of State Protection and other units

${ }^{10}$ Andrzej Milczanowski, Jak trafiłem do Urzędu Ochrony Państwa, Przegląd Bezpieczeństwa Wewnętrznego, special edition, 6 IV 2010, p. 46.

${ }^{11}$ Archiwum Instytutu Pamięci Narodowej - Biuro Udostępniania i Archiwizacji Dokumentów [Archives of The Institute of National Remembrance - Office for the Preservation and Dissemination of the Act Records in Warsaw] (further cit. AIPN BU), 0045/101, Vol. 1. A decree by the Minister of Internal Affairs no $043 / 90$ dated May $10^{\text {th }}, 1990$, concerning the liquidation of the Security Service (SB) c. 204-208.

${ }^{12}$ Archiwum Instytutu Pamięci Narodowej - Delegatura w Bydgoszczy [Archives of The Institute of National Remembrance - Delegation in Bydgoszcz] (further cit. AIPN By), 077/1392, decree no 023/90, by the Head of the Provincial Office of State Protection in Bydgoszcz concerning the liquidation of the Security Service, dated 25 V 1990, signed by the acting head of the Provincial Office of State Protection Colonel Jan Strycharski, c. 42-42v. 
subordinate to the Ministry of Internal Affairs in regards to former Security Service officials.

Finally, on May 21 $1^{\text {st }}, 1990$, the Council of Ministers adopted Act no 69 on the procedures and conditions for employing former Security Service officials in the Office of State Protection, and other organizational units subordinate to the Ministry of Internal Affairs, as well as employing them in the Ministry of Internal Affairs ${ }^{13}$ itself. Pursuant to this act, former Security Service officials (discussed in Article 131 in the Act on the Office of State Protection), could be employed in the Office of State Protection, the Police and in other organizational units subordinate to the Minister of Internal Affairs only after receiving a favourable opinion issued by an appropriate selection committee on the basis of a qualifying procedure.

The Act established the Central Selection Committee [Centralna Komisja Kwalifikacyjna], which was headed by Krzysztof Kozłowski, the Selection Committee for Central Personnel [Komisja Kwalifikacyjna do Spraw Kadr Centralnych], and provincial selection committees [wojewódzkie komisje kwalifikacyjne].

Members of the Central Selection Committee were appointed by the Prime Minister from the representatives of: the Political Advisory Committee at the Ministry of Internal Affairs, the Minister - the head of the Office of the Prime Minister, the Minister of Internal Affairs, the head of the Office of State Protection, the Chief Commander of the Police, the Police officials trade unions, ${ }^{14}$ and other people highly respected in society. People, who were allowed to participate in the work of the Central Selection Committee came from the Parliamentary Commission of Administration and Internal Affairs, and the Senate Commission of Human Rights and Law and Order.

The Selection Committee for the Central Personnel was appointed by the head of the Office of State Protection, and its members were made up of representatives of different authorities and organizations, including parliamentary and senate commissions.

The provincial selection committees (and their chairmen) were appointed by the head of the Central Selection Committee and their members comprised representatives of the head of the Office of State Protection, the Chief Com-

${ }^{13}$ AIPN BU, 1585/17094, decree no 69 by the Council of Ministers, dated May 21 $1^{\text {st }}, 1990$, concerned the procedures and conditions for employing former Security Service officials in the Office of State Protection and other organizational units subordinate to the Minister of Internal Affairs, and their employment in the Ministry of Internal Affairs, see also: Historyczno-prawna analiza struktur organów bezpieczeństwa (1944-1990). Zbiór studiów, ed. Adrian Jusupović, Rafał LeśKIEwICZ, Warszawa 2013, pp. 298-302.

${ }^{14}$ The Decree on the Police in comparison to the Decree on the Office of State Protection took into consideration the possibility of officials forming trade unions. 
mander of the Police, the Police officials' trade unions, and other people highly respected in society.

The Act also specified the tasks to be undertaken for every level of the selection committees with the Central Selection Committee, amongst others, being responsible for supervising the selection process carried out by the Selection Committee for Central Personnel and the Provincial Selection Committees, as well as examining any appeals brought by candidates. The Selection Committee for Central Personnel was responsible for conducting the selection process and forming opinions on candidates previously employed at a central level in organizational units of the Security Service, now applying for a job in the Office of State Protection, the Police or any other organizational units subordinate to the Minister or Ministry of Internal Affairs.

Provincial Selection Committees were responsible for conducting the selection process and forming opinions on candidates applying for jobs in the Office of State Protection, the Police or any other organizational units subordinate to the Minister or Ministry of Internal Affairs.

Provincial Selection Committees were responsible for assessing a candidate's suitability for the job on the basis of the application form, previous personal documents, duty records, and other additional documents. Committee members could initiate an additional interview or organize it on a candidate's request. The assessment depended on the kind of job a candidate applied for but the Committee could recommend a candidate for other services. A person, who was positively vetted, proved that they, in their previous job, had not commited an offence, had not violated human rights and the dignity of anyone in the undertaking of their duties, and had not used their position for personal gain.

The committees provided every candidate with a written decision and Provincial Selection Committees sent positive opinions about successful candidates to the authorities responsible for examining cases concerning their employment in the authorities and units subordinate to the Minister of Internal Affairs; it being a necessary condition for further employment of former Security Service officials.

Krzysztof Kozłowski, as head of the Central Selection Committee issued instructions which specified all positions which required verification. According to these instructions verification applied to: ${ }^{15}$

${ }^{15}$ AIPN By, 719/95, Documentation of the Provincial Selection Committee in Torun concerning verification of Security Service officials, the Instructions by the chair of the Central Selection Committee dated 25 VI 1990, c. 30-33, see: Aparat bezpieczeństwa w Polsce. Kadra kierownicza, 1975-1990, vol. 3, ed. Paweł Piотrowski, Warszawa 2008, p. 21. 
- The officials who on May $10^{\text {th }} 1990$, held the positions of head or deputy head in such services as: Intelligence, Counterintelligence, the Security Service at the Ministry of Internal Affairs, Personnel, Education and Upbringing, Operational Protection, the Minister's advisors, deputy heads of the Provincial Office of Internal Affairs [Wojewódzki Urząd Spraw Wewnętrznych] and the Capital Office of Internal Affairs [Stołeczny Urząd Spraw Wewnętrznych] for the Security Service;

- The officials who on May $10^{\text {th }} 1990$, worked: in Departments I, II, the State Constitutional Order Protection, the Protection of Economy, the Department of Studies and Analyses, Personnel Department (up to the position of junior inspector). It also included personnel in Education and Upbringing - to the position of junior inspector and Technology- up to the position of deputy head. The Operational-Staff Group of the Head of the Security Service, the Secretariat of the Head of the Security Service and the Secretariat of the Intelligence and Counterintelligence Services were also vetted. Others to undergo the process were the Bureau of Investigation, the Cipher Bureau, Bureau 'B' - up to the position of deputy head and Bureau ' $C$ ' Personnel of the Passport Office - up to the position of a deputy head, in the former Administration for Officials' Protection - up to the position of junior inspector, and people who were students and personnel of the Internal Affairs Academy [Akademia Spraw Wewnętrznych] also did not escape. Exceptions were made for the Public Order Department in Szczytno and all corresponding positions in the Provincial Office of Internal Affairs, apart from officials working for the personnel and education and training departments.

- Also vetted were officials who on July $31^{\text {st }} 1989$, held the positions of the head of Intelligence and Counterintelligence Services (and their deputy heads), the head of the Security Service (and his deputy head), the Minister's advisors, the head of the Operational Procurement Service (and his deputy heads), the heads and deputy heads of the Political-Educational Service, Personnel and Professional Improvement; and those who worked in Departments I and II and in the Operational-Staff Group of the Head of the Security Service, the Personnel Department, the Secretariat of the Head of the Security Service and in the Secretariat of the Intelligence and Counterintelligence Services; In addition, people employed in Bureaus 'C' and ' $\mathrm{B}$ ', the Bureau of Investigation, the Passport Office, Technology Department - up to the position of deputy head, the Administration for Officials' Protection - up to the position of junior inspector were also vetted. Others included staff of Departments: III, IV, V, VI, the Bureau of Studies of the Security Service at the Ministry of Internal Affairs, the Main Inspectorate of Industry Protection, the Bureau 'A' and 'RKW', the Political-Educational 
Administration - up to the position of junior inspector and the Ministry of Internal Affairs Military Academy in Legionowo (personnel and students). All corresponding positions in the Provincial Office of Internal Affairs, apart from officials working for personnel, who were transferred to organizational units of the Civic Militia ${ }^{16}$ also had to undergo the process.

Formally, selection committees were set up on July $10^{\text {th }}$, when at a meeting in the Main Personnel Development Centre in Łódź all selection committee members received formal confirmation concerning their appointments from the head of the Office of State Protection, Krzysztof Kozłowski, who was also the Minister of Internal Affairs, after the dismissal of General Czesław Kiszczak on July $7^{\text {th }} 1990$. At the meeting his closest co-workers, who, at that time, formed the structures of the new authority, were present. However, apart from the decision made concerning their appointment to selection committees and from other formal documents, no guidelines were provided in order to standardize the criteria of assessment for the whole country.

The verification process started when Krzysztof Kozłowski and his workers came to office. His deputy was Andrzej Milczanowski. Krzysztof Kozłowski personally made, among others: Konstanty Miodowicz, ${ }^{17}$ Wojciech Raduchowski-Brochwicz, ${ }^{18}$ Bartłomiej Sienkiewicz ${ }^{19}$ and Piotr Niemczyk ${ }^{20}$ responsible for organizing this authority. Later they were joined by: Kazimierz Mordaszewski, ${ }^{21}$ Piotr Stachańczyk ${ }^{22}$ and Adam Hodysz. ${ }^{23}$ All the time they

${ }^{16}$ Ibid. In August 1989 a process of keeping Security Service officials quiet by offering them vacancies in Civic Militia, started. It happened pursuant to a decree issued by the Minister of Internal Affairs, General Czesław Kiszczak. This point was included in the instructions, in order to verify real Security Service officials.

${ }^{17}$ Konstanty Miodowicz (1951-2013) - a graduate of Jagiellonian University, son of Alfred Miodowicz (the chairman of the regime Nationwide Alliance of Trade Unions - Ogólnopolskie Porozumienie Związków Zawodowych), an activist of the Independent Students' Association [Niezależne Zrzeszenie Studentów] from 1980-1981, and later in the 1980s an activist for a pacifist movement called "Wolność i Pokój" (translates as "Freedom and Peace").

${ }^{18}$ Wojciech Raduchowski-Brochwicz (born 1960) - a law graduate of Jagiellonian University.

${ }^{19}$ Bartłomiej Sienkiewicz (born 1961) - a graduate of Jagiellonian University, an activist of the Independent Students' Association from 1980-1981 and later an activist for a pacifist movement called "Wolność i Pokój."

${ }^{20}$ Piotr Niemczyk (born 1962) - editor of "Gazeta Wyborcza" in Szczecin, and in the 1980s a co-founder of the pacifist movement called "Wolność i Pokój."

${ }^{21}$ Kazimierz Mordaszewski (born 1960) - a legal advisor, law graduate of Nicolaus Copernicus University in Toruń. In the 1980s and an activist for both the Independent Students' Association and the Association of Democratic Youth [Związek Młodzieży Demokratycznej].

${ }^{22}$ Piotr Stachańczyk (born 1962) - then a student of the Faculty of Law at Jagiellonian University.

${ }^{23}$ Adam Hodysz (born 1940) - in 1984 as a Security Service official he was arrested and sentenced to eight years for cooperating with the underground "Solidarity" movement. 
worked in close cooperation with Jan Widacki ${ }^{24}$ and Jerzy Zimowski. ${ }^{25}$ This team, consisting of former opposition activists, immediately started forming the organizational structure of the Office of State Protection.

However, before the verification process started, by the end of May 1990, more than twenty senior military officers of the Ministry of Internal Affairs had handed in their resignation (or had been dismissed), including 10 generals. Among those leaving there were: Krzysztof. Majchrowski from the Department of the State Constitutional Order Protection, General Tadeusz Szczygieł - the head of Department I, General Lucjan Czubiński - the Deputy Minister of the Ministry of Internal Affairs, Colonel Jerzy Karpacz - the head of the Security Service and Chief Commander of the Civic Militia [Milicja Obywatelska] - General Zenon Trzciński. In total, at that time, 16 department heads, 32 deputy heads, 34 provincial chiefs and 86 of their deputies left. From the previous total of 137 department management in Rakowiecka Street only 20 remained. By May, 1990, 90\% of the members of the extended department council left the headquarters of the Ministry of Internal Affairs. Only four generals: the Commander of the Vistula Military Units - General Edward Wejner, the Commissioner in Łódź - General Marek Ochocki, the Fire Department Chief - General Marek Stefanowski and General Zdzisław Sarewicz ${ }^{26}$ remained.

Those who followed suit by handing in their resignation were the officials of former departments III, IV and the Cipher Bureau, which had been disgraced. Andrzej Milczanowski was appointed the chairman of the Selection Committee for Central Personnel and in this committee were also to be found, among others, Bartłomiej Sienkiewicz, Wojciech Brochwicz and Jerzy Zimowski. Wojciech Brochwicz would say many years later in an interview with Grzegorz Chlasta that those who came were not frightened and were answering the call that was being made of them. If unclear situations arose other officials' statements were taken into consideration, and also people who had been re-

${ }^{24}$ Jan Widacki (born 1948) - then an employee of the Forensic Science Department at the Faculty of Law of the Catholic University in Lublin and the co-author of the so called police laws. He was Krzysztof Kozłowski’s advisor, later Deputy Minister of Internal Affairs.

${ }^{25}$ Jerzy Zimowski (born 1941) - deputy of the Parliamentary Civic Club, then vice-president of the Parliamentary Administration Committee and later the Deputy Minister of Internal Affairs

${ }^{26} \mathrm{He}$ was sent to a counter-intelligence group in Moscow (Grupa "Wisła"). This group existed in Moscow at the time of PRL as a result of an agreement dated January 1957 between the Ministry of Internal Affairs of PRL and the Committee of the State Security of USSR - KGB. It aimed at monitoring Polish citizens staying in the USSR, including delegates of PRL in the Council for Mutual Economic Assistance [Rada Wzajemnej Pomocy Gospodarczej - RWPG], representatives of sales centres, participants of fairs, exhibitions and scientific conferences, reporters, students and contractual workers. From 1985 it undertook political intelligence activities. 
pressed by a certain officer were called. In every committee there was an officer from the unit whose officials were being verified present acting as an informal advocate (as every department was verified separately). In the case of intelligence, Gromosław Czempiński fulfilled the role. In the case of counterintelligence, Andrzej Sroka, head of this department was such an officer. In addition, every officer ${ }^{27}$ had the right to offer an opinion.

As Krzysztof Kozłowski later admitted, more than 90\% of departmental management who had fought the opposition and the Catholic Church handed in their resignations. Only a few underwent the verification procedure, (and only a handful of these were positively verified). Polish services did not need experts in these areas, their services were no longer required.

At a local level there were created 48 Provincial Selection Committees (and the Municipal Selection Committee for the City of Warsaw). Their chairmen were people associated with "Solidarity" or highly respected members of society. Among members of the Provincial Selection Committees there were: Provincial Commissioners as representatives of the Chief of the Police, representatives of the head of the Office of State Protection (in some committees both functions were performed by Provincial Commissioners), representatives of the Police Officials' Trade Unions and Deputies and Senators from the Civic Parliamentary Club. Every member had to sign a special declaration, requiring their work to be kept secret. ${ }^{28}$

A lack of detailed standardized assessment criteria for the whole country had a major bearing on the work of the Provincial Selection Committees. It turned out that there were big discrepancies in assessing candidates for the service, and in some committees the number of negatively verified officials reached as high as $80 \%$, whereas in others only $8 \%$. Paradoxically, the highest percentage of rejections occurred in the committees, which operated in areas where opposition activities were very rare, which meant that Security Service officials had not performed intensive operational investigations there. In comparison, the Gdańsk Committee rejected only $8 \%$ of candidates for the new service..$^{29}$ The lack of guidelines caused situations where candidates could be rejected on moral grounds'. Due to the high number of complaints which arose, the Central Selection Committee organized a meeting, where they tried to standardize the assessment criteria. Jan Widacki, the previous Deputy Mi-

${ }^{27}$ Grzegorz Chlasta, Czterech. Brochwicz, Miodowicz, Niemczyk, Sienkiewicz, Warszawa 2014, p. 35.

${ }^{28}$ AIPN By, 719/95, Documentation of the Provincial Selection Committee in Torun concerning verification of Security Service officials, dated 1 VII 1990.

${ }^{29}$ Witold Bereś, Krzysztof BurnetKo, Gliniarz $z$ „Tygodnika”, Rozmowy z byłym ministrem spraw wewnętrznych Krzysztofem Kozłowskim, Warszawa, [no edition date], p. 42. 
nister of Internal Affairs, sent a letter to provincial committees, in which he exhorted: "While [...] assessing, we have to remember that we are not a tribunal judging on the basis of «revolutionary conscience», but an institution, which applies existing laws/ in a democratic country and a sovereign nation, which has belonged to the Christian part of western culture for many years. We have to remember that our heritage obliges us to behave in a certain way. In the Christian part of western culture administering justice differs from revenge. Collective responsibility is rejected, and people are assessed individually. The prosecutor has to prove guilt, not the accused innocence. Doubts always work in favour of the accused". ${ }^{30}$

Members of Provincial Selection Committees had similar feelings concerning the verification process. Parliament members, who were obliged to participate in committee work in their areas, were in most cases unwilling to do so. Some of them were of the opinion that the verification process was badly thought over and disorganized. Others were unwilling to participate because they were worried their image would suffer as a result.

By July $31^{\text {st }}$, when the proceedings had finished at provincial committees, 14,034 people had been verified. Among them were 8,658 people $(61.7 \%)$ who were verified positively. Of the 5,376 people who were not accepted, 4,771 (about 89\%) complained to the Central Selection Committee. The Central Selection Committee reversed the decision for 1,781 (37.3\%) of them, but upheld the initial negative decisions for 2,990 people. In total 10,439 were vetted positively, whereas 3,595 were not. 3,028 officials in the police force received negative verifications whilst the majority who were verified positively became officials of the Office of State Protection or the Police ${ }^{31}$ on August $1^{\text {st }} 1990$.

\section{CONCLUSION}

Secret Service post communist reform in Poland did not consider the so called "zero option," but instead devised an intermediate hybrid model.

On the one hand, placing the Office of State Protection under the auspices of the Ministry of Internal Affairs, making it responsible for Intelligence and Counterintelligence, enabling previous officials to work in the new structure, and promoting them to managerial positions, provided powerful arguments for the continuation option.

On the other hand, focus needs to be placed on the organizational structure of the Office of State Protection, which resulted from an acute need for a centralized authority arising from parliamentary legislation debates. As

${ }^{30}$ Jan WidACKI, Czego nie powiedział generał Kiszczak, Warszawa 1992, p. 28.

${ }^{31}$ Aparat bezpieczeństwa w Polsce. Kadra kierownicza, p. 22. 
a consequence, 14 delegations of the Office of State Protection were formed from the 49 existing provinces. In contrast to Communist times these delegations were independent of the Police and had their own offices). At central and regional levels units, unknown in communist times, were created responsible for so called white intelligence and the methods and tools of operational activities were also changed.

Verification was based on an Act of the Office of State Protection, and regulated by a decree issued by the Council of Ministers. Verification committees completed their tasks in different ways, depending on the level of external pressure exerted. It must be admitted that the key issue of officers receiving training in the centres of the State Security Agency [Komitet Bezpieczeństwa Państwowego] in the USSR, and cooperating with these authorities in regards to common intelligence operations, was absent from the verification process. A discriminating argument what was taken into consideration during the verification process was whether the person being vetted had been involved in brutally suppressing the national opposition or not. ${ }^{32}$

In the security services, there was a healthy aversion to the Office of State Protection, which was very common in society, but gradually new people unconnected with the previous regime started to appear and underwent the training process. However, at the beginning of 1990 almost $90 \%$ of management came from the Security Service, and all key managerial positions (Intelligence, Counterintelligence, Investigatory Board, Technology Office, Financial Office and Cipher Bureau) were held by former colonels. New young blood were appointed heads of the newly established units of white intelligence ${ }^{33}$ while at delegation level, their heads came from people from a "Solidarity" background but their deputies had connections with the Security Service. ${ }^{34}$

The adoption of these measures resulted in a situation, where the security service personnel problem was returned to in public debates and used as a political weapon for many years. However, verification was meant to be the lesser evil, which would not deprive the state of internal and external protection. The training process for intelligence and counterintelligence officers lasted for a minimum of 5 years; depriving the state of security for this period of time. In a situation of burgeoning crime, the opening of borders, a crisis in the USSR,

${ }^{32}$ Piotr Woyciechowski, Antoni Podolski, Lojalność wobec sojuszników, Rzeczpospolita, 12 VI 1997.

${ }^{33}$ Krzysztof KozŁowski, Rewolucja po polsku, Przegląd Bezpieczeństwa Wewnętrznego, special edition, 6 IV 2010, pp. 16-17.

${ }^{34}$ Michał Stręк, Wyzwanie, Przegląd Bezpieczeństwa Wewnętrznego, special edition, 6 IV 2010, p. 73. 
the process of incorporating the German Democratic Republic into the Federal Republic of Germany (which involved the crossing of 26 Soviet motorized and tank divisions) through Polish territory and the quartering of the Northern Group of the Soviet Army, the lack of a fully operational secret service could have been disastrous. ${ }^{35}$ It was essential to have a fully operational authority in situations where borders were being opened, poverty was increasing, and the number of illegal companies was on the rise opening up opportunities for some to take advantage. All of these factors created ideal conditions for criminal organizations to take root and these organizations were rich enough to bribe politicians, and drain a significant amount of public funds. ${ }^{36}$

The verification process threw up further problems concerning former Security Service officers who were negatively rejected and dismissed officials who started new careers in private institutions or set up their own companies (equipped with better and more modern equipment), and then competed with state organizations, or became involved in the activities of organized crime groups.

The process of forming new services in a new political reality was eased by the amount of help provided by western countries. If it had not been for this external help, the results of the transformative activities in the security services would have been insufficiently or even disastrous. ${ }^{37}$ Poland could count on help provided by western countries in effectively dealing with threats, which surfaced at the end of the cold war; threats which also affected the national security of the European Union and NATO.$^{38}$ In this way Polish security services could lean on the experience of western services. However, $t$ this help was not unconditional, as there was some risk that service reform would be of a superficial nature. This may have appeared the case given the fact that former Security Service officials remained in the newly formed security services, and they might well have had some connections with the Soviet State Security Agency, especially because the bonds between the Soviet State Security Agency and the Central Intelligence Board [Główny Zarząd Wywiadowczy - GRU] were not broken. Up to the end of 1991 there was still a special communication system in place between Poland and the countries of the former USSR. There were alert shifts in the system of integrated contacts with Moscow. In addition, intelligence- activity-expenses arising from the liquidation of the Warsaw Pact

${ }^{35}$ P. Woyciechowski, A. Podolski, op.cit.

${ }^{36}$ Lawrence Lustgarten, National Security and Political Policing: Some Thoughts on Values, Ends and Law, [in:] Democracy, Law and Security: Internal Security Services in Contemporary Europe, ed. Jean-Paul Brodeur, Peter Gill, Dennis Tollborg, Ashgate 2003, p. 331.

${ }^{37}$ L. WATTS, op.cit., p. 19.

${ }^{38}$ Ibid. 
were never accounted for, such as the Integrated System of the Enemy Data [Połączony System Ewidencji Danych o Przeciwniku - PSED], which was an integrated IT system with its headquarters in Moscow, involving all the countries of the European Eastern Block and some Asian countries (for instance Vietnam), whose aim was to gather and process information obtained in security service ${ }^{39}$ operations.

A natural consequence of adopted models elsewhere was the rooting out of former Security Service officials. However, in Poland this process was halted after 1993, when the left-wing party won the election. However, it reared its ugly head again during the joining of NATO negotiations. It has to be mentioned that in 1996 there were still about 50\% of former Security Service officials employed in the security service.

Was it possible to adopt a different solution in Poland at this time? This has remained unanswered for more than twenty-five years. A lack of governing experience and a lack of knowledge of security service reform were key at that time. As was said before, the team with responsibility for establishing the Office of State Protection consisted of a few young people from an opposition background, who had to work out the basic standards and norms themselves. As a result they quite naturally, relied on previous practice only adding some new elements to it as they saw fit. It has to be emphasized that at the time they started working for the Office of State Protection, the old intelligence and counterintelligence were still in place and the head of the department was a communist general surrounded by his own closest team.

Another factor added to the mix in secret service change was the lack of any real government involvement. It has to be said that the Prime Minister, Tadeusz Mazowiecki, advocated against more radical reforms, which wished to require making the Office of State Protection report directly to the Prime Minister and separate its internal structure. By making the Office of State Protection subordinate to the Ministry of Internal Affairs, he relegated the issue of its functioning to a secondary status. Krzysztof Kozłowski, at a Senate debate on enacting the law said: "[...] The Prime Minister does not want to be personally responsible for the possible failures of the Office of State Protection, especially its intelligence. Let's be fair, and not make the Prime Minister directly responsible for ... as the Minister of Internal Affairs is the one to be held responsible".40

${ }^{39}$ P. Woyciechowski, A. Podolski, op.cit.

${ }^{40}$ Verbatim report of the $23^{\text {rd }}$ meeting of the Senate of the People's Republic, April $26^{\text {th }}-27^{\text {th }}$, 1990, https://bs.sejm.gov.pl/exlibris/aleph/a22_1/apache_media/99VKM8LQVX4KJ2T6PR3IP B56RPHRPF.pdf, [access: 22 XI 2015]. 
Political and economic reforms took precedence, which resulted in a lack of radical solutions being offered for how the secret service ${ }^{41}$ was to function.

\section{Trans. by Katarzyna Kilińska-Gacka \\ Thomas Anderson}

Nadesłany: 25 I 2017

Nadesłany po poprawkach recenzyjnych: $20 \mathrm{~V} 2017$

Zaakceptowany: 26 V 2017

Prof. dr hab. Wojciech Polak

Wydział Politologii i Studiów Międzynarodowych

Uniwersytet Mikołaja Kopernika w Toruniu

e-mail:wp@umk.pl

Dr Sylwia Galij-Skarbińska

Wydział Politologii i Studiów Międzynarodowych

Uniwersytet Mikołaja Kopernika w Toruniu

e-mail: sgs@umk.pl

${ }^{41}$ As was the case in other post-communist countries, which chose the so called "zero option," it was impossible to follow through with it to the end. As a matter of fact data provided by these countries (Czechoslovakia and the countries on the Baltic Sea) indicate that 5\% to $10 \%$ of former service personnel were retained. They 1 mainly worked in subsidiary and technical services, and only a small number of them found employment in operational units, especially intelligence. It is worth adding that after 1990 Czechoslovakia was the most dynamic in regards to change as it reduced the number of STB ex-officers from $14 \%$ in 1991 to $4 \%$ in 1993 , see: Kieran Williams, Czechoslovakia 1990-1992, [in:] K. Williams, D. Deletant, op.cit., p. 69.

\section{POLSKI MODEL}

REFORMY CYWILNYCH SŁUŻB SPECJALNYCH W 1990 ROKU

\section{Streszczenie}

Słowa kluczowe: Służba Bezpieczeństwa, Urząd Ochrony Państwa, weryfikacja, Ministerstwo Spraw Wewnętrznych

Debata o kształcie przyszłych służb, jaka na przełomie roku 1989 i 1990 rozgorzała nie tylko w parlamencie, lecz także w mediach, ujawniła liczną grupę ekspertów, publicystów i polityków różnej proweniencji politycznej, opowiadających się za radykalnymi reformami. Różnice między nimi polegały tylko na wyborze jednej z dwóch ścieżek realizacji tego postulatu: albo „opcja zerowa”, albo „kontynuacja” dotychczasowych rozwiązań przez zaadaptowanie ich na potrzeby państwa demokratycznego. Okazuje się jednak, że dróg rozwiązań było wiele. „Opcja zerowa” i „kontynuacja” stanowią dwa antynomiczne typy, między którymi na kontinuum rozciąga się wiele form 
gradualistycznych. O ich położeniu decydują takie czynniki, jak: „sposób odchodzenia od komunizmu”, poziom doświadczenia i wiedzy rządzących na temat reformy służb specjalnych, zaangażowanie ekipy rządzącej na tym obszarze. Dopiero wówczas można je uszeregować ze względu na charakter struktury organizacyjnej, ulokowanie w strukturze władz państwowych, metod działania, wymiany personelu (w tym kadry kierowniczej). Celem artykułu jest ukazanie rozwiązań zastosowanych w przypadku Polski w roku 1990 przez pryzmat czynników, które je determinowały.

\section{Das POLNISCHe MODELL}

DER Reform Des Zivilen Geheimdiensts im JAHR 1990

\section{Zusammenfassung}

Schlüsselwörter: Sicherheitsdienst, Amt für Staatsschutz, Verifizierung, Innenministerium, Geheimdienst, Reform

In der Debatte über die künftige Form des Geheimdiensts, die an der Jahreswende 1989/90 nicht nur im Parlament, sondern auch in den Medien entbrannte, trat eine große Gruppe von Experten, Publizisten und Politikern verschiedener Herkunft auf, die sich für radikale Reformen aussprachen. Die Unterschiede zwischen ihnen bestanden nur in der Befürwortung eines von zwei Wegen zur Verwirklichung dieser Forderung: entweder eine "Null-Option“ oder die „Fortführung" der bisherigen Regelung durch Anpassung an die Bedürfnisse eines demokratischen Staats. Bei näherer Betrachtung zeigt sich jedoch, dass es viele Lösungswege gab. Die „Null-Option“ und die „Fortführung" bildeten zwei entgegengesetzte Typen, zwischen denen es viele Arten von Abstufungen gab. Über ihre Bewertung entschieden Faktoren wie „die Art der Abkehr vom Kommunismus", der Grad der Erfahrung und des Wissens bei den Regierenden zum Thema Reform der Geheimdienste und das Engagement der jeweiligen Regierung in diesem Bereich. Damals ließen sie sich nur einordnen nach der Organisationsstruktur, nach ihrer Stellung in der Struktur der Staatsmacht, der Arbeitsweise, des Personalsaustauschs (darunter auch des Führungspersonals). Die vorliegende Arbeit soll die Lösungen, die im Falle Polens gefunden wurden, im Licht der Faktoren zeigen, die sie beeinflussten. 
A Polish model of the intelligence service reform in 1990

\section{BIBLIOGRAPHY}

Bereś, Witold, Krzysztof Burnetko. Gliniarz z „Tygodnika”, Rozmowy z byłym ministrem spraw wewnętrznych Krzysztofem Kozłowskim. Warszawa: BGW, 1991.

Bruneau, Thomas C., Florina C. Matei. "Intelligence in the Developing Democracies: The Quest for Transparency And Effectiveness". Access: 22.11.2015. http://www. resdal.org/producciones-miembros/art-bruneau-other-mar10.pdf

Bruneau, Thomas C., Kenneth R. Dombroski. "Reforming Intelligence: The Challenge of Control in New Democracies". In: Who Guards the Guardians and How. Democratic Civil-Military Relations, eds. Thomas C. Bruneau, Scott D. Tollefso. Austin: University of Texas Press, 2006.

Chlasta, Grzegorz. Czterech: Brochwicz, Miodowicz, Niemczyk, Sienkiewicz. Warszawa: Wydawnictwo Czarna Owca, 2014.

Jusupović, Adrian, Rafał Leśkiewicz, eds. Historyczno-prawna analiza struktur organów bezpieczeństwa (1944-1990). Zbiór studiów. Warszawa: IPN, 2013.

Kozłowski, Krzysztof, Michał Komar. Historia z konsekwencjami. Warszawa: "Świat Książki”, 2009.

Kozłowski, Krzysztof. "Rewolucja po polsku”. Przegląd Bezpieczeństwa Wewnętrznego, 6.04.2010.

Lustgarten, Lawrence. "National Security and Political Policing: Some Thoughts on Values, Ends and Law". In: Democracy, Law and Security: Internal Security Services in Contemporary Europe, eds. Jean-Paul Brodeur, Peter Gill, Dennis Tollborg. Ashgate: Routledge, 2003.

Milczanowski, Andrzej. “Jak trafiłem do Urzędu Ochrony Państwa”. Przegląd Bezpieczeństwa Wewnętrznego, 6.04.2010.

Piotrowski, Pawel, ed. Aparat bezpieczeństwa w Polsce: kadra kierownicza, vol. 3: 1975-1990. Warszawa: IPN, 2008.

Stręk, Michał. "Wyzwanie”. Przegląd Bezpieczeństwa Wewnętrznego, 6.04.2010.

Warner, Michael. "Building a Theory of Intelligence Systems". In: Mapping the State of Research on Intelligence, ed. Gregory Treverton. New York: Cambridge University Press, 2009.

Watts, Larry. "Intelligence Reform in Europe's Emerging Democracies". Studies in Intelligence 48/1 (2004): 11-25.

Widacki, Jan. Czego nie powiedział generał Kiszczak. Warszawa: BGW, 1992.

Williams, Kieran, Dennis Deletant. Security Intelligence Services in New Democracies The Czech Republic, Slovakia and Romania. London: Palgrave Macmillan, 2001.

Williams, Kieran. “Czechoslovakia 1990-1992”. In: Kieran Williams, Dennis Deletant. Security Intelligence Services in New Democracies The Czech Republic, Slovakia and Romania, 55-82. London: Palgrave Macmillan, 2001.

Williams, Kieran. "Introduction". In: Kieran Williams, Dennis Deletant. Security Intelligence Services in New Democracies The Czech Republic, Slovakia and Romania, 1-23. London: Palgrave Macmillan, 2001.

Woyciechowski, Piotr, Antoni Podolski. “Lojalność wobec sojuszników”. Rzeczpospolita, 12.06.1997. 